\title{
GC-MS EXAMINATION OF METHANOLIC EXTRACT OF Cirsium arvense FLOWERS
}

\section{${ }^{*}$ Malik F. H. Ferdosi ${ }^{1}$, Iqra Haider Khan ${ }^{2}$, Arshad Javaid ${ }^{2}$ and Muhammad F. A.} Fardosi ${ }^{3}$

DOI: $\underline{\text { https://doi.org/10.28941/pjwsr.v27i2.946 }}$

\begin{abstract}
Cirsium arvense (L.) Scop., commonly known as creeping thistle, is a weed of Asteraceae. This study was undertaken to explore various phytoconstituents present in flower of this weed. To achieve this goal, the dried flowers of this weed were soaked in methanol for one week and filtered. This methanolic extract was subjected to GC-MS analysis and 7 compounds were identified. These included olean-12-en-3-ol, acetate, (3 $\beta$ )$(63.87 \%)$, lanosta-8,24-dien-3-ol, acetate, $(3 \beta)$ - (12.12\%), $\beta$-amyrin $(6.19 \%)$, $\gamma$-sitosterol $(6.09 \%)$, a-amyrin (5.24\%), stigmasterol (3.29\%) and carbonic acid, 2-ethylhexyl heptadecyl ester (3.16\%). Literature survey showed that these compounds possess antiinflamatory, antimicrobial, antidiabetic, antioxidant and/or anticancer activities.
\end{abstract}

Keywords: Creeping thistle, Flower extract, GC-MS analysis, Phytochemicals.

Citation: Ferdosi, M.F.H., I.H. Khan, A. Javaid, M.F.A. Fardosi. 2021. GC-MS Examination of Methanolic Extract of Cirsium arvense Flower. Pak. J. Weed Sci. Res., 27 (2):173-180.

\footnotetext{
${ }^{1}$ Department of Horticulture, Faculty of Agricultural Sciences, University of the Punjab, Quaid-e-Azam Campus, Lahore 54590, Pakistan

${ }^{2}$ Department of Plant Pathology, Faculty of Agricultural Sciences, University of the Punjab, Quaid-e-Azam Campus, Lahore 54590, Pakistan

${ }^{3}$ Institute of Botany, University of the Punjab, Quaid-e-Azam Campus, Lahore 54590, Pakistan

*Corresponding author's email: fiaz.iags@pu.edu.pk, malikferdosi@yahoo.com
} 


\section{INTRODUCTION}

Natural compounds isolated from plants have recently become of great interest because of their variable biological applications (Lichota and Gwozdzinski, 2018; Javed et al., 2021). These are considered as the affluent bioresource of food supplements, nutraceuticals, pharmaceutical intermediates as well as folk, traditional and modern medicine systems (Jamiołkowska, 2020; Khan and Javaid, 2020a). It has been estimated that 15$29 \%$ of higher plant species extract contain synergistic effects and polypharmacological applications to treat human as well as plant diseases (Yuan et al., 2017). The identification and purification of active principles produced by plants are of supreme importance to ensure their efficacy and safety in pharmaceuticals (Jiménez-Reyes et al., 2019). The determination of phytoconstituents is largely dependent on the solvent type, which is used for extraction. So far, methanol is one of the most commonly used solvents to investigate the biological activities from plant extracts (Sauerschnig et al., 2018; Banaras et al., 2021). Moreover, dried or fresh plant materials exist in their biologically active forms and are used as a source of secondary components (Ingle et al., 2017; Javaid et al., 2018). Many scientists are working on the phytoconstituents and have attracted the attention of scientific communities towards the application of dried plant materials in agriculture and pharmacology (Ali et al., 2020; Khan and Javaid, 2020a,b).

Cirsium arvense, family Asteraceae, is native to Western Asia, Europe, North Africa, eastern United States and Canada (Nobarinezhad et al., 2020). It is very common in different parts of the province Punjab. It is a perennial persistent noxious weed plant that expands vigorously by horizontally grown roots and forms dense colonies (Verbeek and Kotanen, 2019). It spreads through wind or as a contaminant in seed crops in the temperate parts of the world.
It infests many habitats such as roadsides, cultivated fields, rangelands, pastures, embankments, lawns and railways (Carter and Lym, 2017). It is a source of tannins, triterpenes, sterols, phenolic acids, coumarins and flavonoids (Dehjurian et al., 2017). It showed antifungal activity against Macrophomina phaseolina (Banaras et al., 2017) and allelopathic potential against weeds and crop plants (Bajwa and Javaid, 1995; Akhtar et al., 2001). It has medicinal uses for the treatment of metrorrhagia, epitasis, syphilis eye infections, bleeding piles, skin sores gonorrhoea, leukaemia, peptic ulcer and tuberculosis (Amiri et al., 2018). Information regarding phytochemical analysis of flower extract of this weed growing in Pakistan is lacking. Thus, the present study was carried out to explore the phytochemical profile and biological active constituents from the methanolic extract of $C$. arvense flowers.

\section{MATERIALS AND METHODS}

\section{Preparation of methanolic extract}

The full bloomed flowers of $C$. arvense were collected from Lahore, Pakistan. The plant species was identified by a botanist Dr. Arshad Javaid (also an author of this paper). The collected material was shifted to the lab to dry under shade conditions. For full drying, the specimen was put in an electric oven at $35{ }^{\circ} \mathrm{C}$ for 5 hours, grinded into powdered form and completely soaked in commercial grade methanol in closed media bottle for 15 days. Then the solvent was filtered by using double filter paper and $2 \mathrm{~mL}$ sample was taken into a glass vial for GC-MS analysis.

\section{GC-MS analysis}

The sample was analyzed by GCMS for the identification of various components of methanolic flower extract of C. arvense. The spectrum of each compound was compared with the compounds in library and arranged in the ascending order of their retention times. The relative abundance was reported by using their peak areas. The structures of the identified natural compounds were drawn by using ChemDraw software. The set GC-MS conditions are given in Table 1. 
Table 1: GC-MS conditions.

\begin{tabular}{ll}
\hline $\begin{array}{l}\text { GC Program } \\
\text { Column }\end{array}$ & DB-5MS (nonpolar) \\
Equipment & Agilent Technologies \\
Injection Temperature & $250^{\circ} \mathrm{C}$ \\
Carrier gas & Helium gas $1 \mathrm{~mL} \mathrm{~m}$ \\
Detector & Mass detector \\
Software & Mass Hunter \\
Sample injection & $1 \mu \mathrm{L}$ \\
Oven ramping & Initial $500^{\circ} \mathrm{C}$ and th \\
Total GC run time & $50 \mathrm{~min}$ \\
& \\
MS program & \\
Library used & $\mathrm{NIST}$ version 2017 \\
Inlet line temperature & $2800^{\circ} \mathrm{C}$ \\
Source temperature & $2300^{\circ} \mathrm{C}$ \\
Quadrupole Temperature & $1500^{\circ} \mathrm{C}$ \\
Mode:Scan (m/z) & $50-500$ \\
Solvent delay & $3 \mathrm{~min}$ \\
Ionization voltage & $70 \mathrm{eV}$ \\
Total MS run time & $50 \mathrm{~min}$ \\
\hline
\end{tabular}

Literature survey

An online extensive survey of the relevant published scientific articles for finding out the bioactivity of identified natural components of methanolic flower extract of $C$. arvense was performed.

\section{RESULTS AND DISCUSSION}

Details of the seven natural compounds identified in this study are given in Table 2 while their properties are presented in Table 3. The predominant compound in this study was olean-12-en3 -ol, acetate, (3 $\beta$ )- with $63.87 \%$ peak area. The second most abundant compound was lanosta-8,24-dien-3-ol, acetate, (3 3 )- with $12.12 \%$ peak area. Other compounds identified in this study were $\beta$-amyrin $(6.19 \%), \quad \gamma$-sitosterol $(6.09 \%)$, a-amyrin $(5.24 \%)$, stigmasterol (3.29\%) and carbonic acid, 2-ethylhexyl heptadecyl ester (3.16\%). Structures of these compounds are presented in Fig. 1.

The most abundant compound in this study was olean-12-en-3-ol, acetate, (3ß)-. It is also known as 3- $\beta$ acetoxyolean-12-ene or $\beta$-amyrin 3acetate. Previously, this compound has been identified in Cornus macrophylla as the fifth most abundant compound (Akbar et al., 2020). It has also been reported in Sambucus chinese (Yang and Lin, 2004).
Fruit of Manilkara subsericea is a rich source of this substance as $72.81 \%$ of its hexanic extract was composed of mixture of a-and $\beta$-amyrin 3-acetate (Fernandes et al., 2013). Both of these isomers possess anti-inflammatory activity (Akihisa et al., 2010). In addition, $\beta$ amyrin 3-acetate also showed antibacterial activity by inhibiting the growth of Staphylococcus aureus (Hichri et al., 2003).

a-Amyrin and $\beta$-amyrin were found as moderately abundant compounds in the present study. The amyrins are present in three forms namely $a^{-}, \beta$ - and $\delta$-amyrin, each having a pentacyclic triterpenol and formula $\mathrm{C}_{30} \mathrm{H}_{50} \mathrm{O}$. They are extensively found in nature and have been identified in a number of plant species including Myrcianthes pungens and Strobilanthes callosus (Singh et al., 2002; Cardoso et al., 2020). The a- and $\beta$-amyrin from Protium heptaphyllum have many pharmacological actions in many systems, for example immunological system and gastrointestinal tract (Nogueira et al., 2019). These are also known to have antioxidant, antimicrobial and antiinflammatory activities (Singh et al., 2002; Cardoso et al., 2020). These compounds can be used as therapeutic 
agents to treat periodontitis and gingivitis because they adjust acute periodontal inflammation by lowering oxidative stress and neutrophils infiltration, and by producing pro-inflammatory cytokine TNFa (Pinto et al., 2008).

Stigmasterol was identified as a minor compound in this study. It is an unsaturated sterol that has been isolated from a number of medicinal plants. It involves in the formation of various hormones such as estrogens, progesterone, corticoids and androgens. Moreover, its various derivatives such as cyasterone, spinasterol, stigmasterol glucoside, fucosterol, fucosterol epoxide, etc. have been identified and their pharmacological aspects have been observed (Kaur et al., 2011). Zeb et al. (2017) isolated this compound from roots of Indigofera heterantha and reported its anti-inflamatory activity. Wang et al. (2017) identified this compound in soybean oil and reported its anti-diabetic activity. Stigmasterol isolated from Inula britannica showed lethal effect against the mite Tetranychus cinnabarinus (Cheng et al., 2012). Y-Sitosterol was a moderately abundant compound in this study and is known to possess anticancer and antidiabetic potential (Balamurugan et al., 2011; Sundarraj et al., 2012).

Table 1: Compounds in methanolic flower extract of Cirsium arvense.

\begin{tabular}{|c|c|c|c|c|c|}
\hline $\begin{array}{l}\text { Sr. } \\
\text { No. }\end{array}$ & Names of compounds & $\begin{array}{l}\text { Molecular } \\
\text { formula }\end{array}$ & $\begin{array}{l}\text { Molecula } \\
\text { r weight }\end{array}$ & $\begin{array}{l}\text { Retention } \\
\text { time (min) }\end{array}$ & $\begin{array}{c}\text { Peak } \\
\text { area } \\
(\%)\end{array}$ \\
\hline 1 & $\begin{array}{l}\text { Carbonic acid, 2-ethylhexyl } \\
\text { heptadecyl ester }\end{array}$ & $\mathrm{C}_{27} \mathrm{H}_{54} \mathrm{O}_{3}$ & 426.7 & 15.879 & 3.16 \\
\hline 2 & Stigmasterol & $\mathrm{C}_{29} \mathrm{H}_{48} \mathrm{O}$ & 412.7 & 45.874 & 3.29 \\
\hline 3 & Y-Sitosterol & $\mathrm{C}_{29} \mathrm{H}_{50} \mathrm{O}$ & 414.70 & 47.463 & 6.09 \\
\hline 4 & $\beta$-Amyrin & $\mathrm{C}_{30} \mathrm{H}_{50} \mathrm{O}$ & 426.7 & 48.244 & 6.19 \\
\hline 5 & a-Amyrin & $\mathrm{C}_{30} \mathrm{H}_{50} \mathrm{O}$ & 426.7 & 49.463 & 5.24 \\
\hline 6 & $\begin{array}{l}\text { Lanosta-8,24-dien-3-ol, } \\
\text { acetate, }(3 \beta) \text { - }\end{array}$ & $\mathrm{C}_{32} \mathrm{H}_{52} \mathrm{O}_{2}$ & 468.75 & 49.961 & 12.12 \\
\hline 7 & $\begin{array}{l}\text { Olean-12-en-3-ol, acetate, } \\
(3 \beta) \text { - }\end{array}$ & $\mathrm{C}_{32} \mathrm{H}_{52} \mathrm{O}_{2}$ & 468.75 & 50.763 & 63.87 \\
\hline
\end{tabular}

Table 2: Bioactivity of components of methanolic flower extract of Cirsium arvense.

\begin{tabular}{|c|c|c|c|}
\hline Sr. No. & Names of compounds & Bioactivity & Reference \\
\hline 1 & $\begin{array}{l}\text { Carbonic acid, 2-ethylhexyl } \\
\text { heptadecyl ester }\end{array}$ & - & - \\
\hline 2 & Stigmasterol & $\begin{array}{l}\text { Anti-inflammatory, } \\
\text { anti-diabetic, acaricidal }\end{array}$ & $\begin{array}{l}\text { Cheng et al. (2012); } \\
\text { Wang et al. (2017); } \\
\text { Zeb et al. (2017) }\end{array}$ \\
\hline 3 & $\mathrm{Y}$-Sitosterol & $\begin{array}{c}\text { Antidiabetic, } \\
\text { anticancer }\end{array}$ & $\begin{array}{c}\text { Balamurugan et al. } \\
\text { (2011); Sundarraj et } \\
\text { al. (2012) }\end{array}$ \\
\hline 4 & $\beta$-Amyrin & $\begin{array}{l}\text { Antioxidant, anti- } \\
\text { inflammatory, } \\
\text { antimicrobial }\end{array}$ & $\begin{array}{l}\text { Singh et al. (2002); } \\
\text { Cardoso et al. (2020) }\end{array}$ \\
\hline 5 & a-Amyrin & $\begin{array}{l}\text { Anti-inflammatory, } \\
\text { antioxidant, } \\
\text { antimicrobial }\end{array}$ & $\begin{array}{l}\text { Singh et al. (2002); } \\
\text { Cardoso et al. (2020) }\end{array}$ \\
\hline 6 & $\begin{array}{l}\text { Lanosta-8,24-dien-3-ol, } \\
\text { acetate, }(3 \beta) \text { - }\end{array}$ & - & - \\
\hline 7 & $\begin{array}{l}\text { Olean-12-en-3-ol, acetate, } \\
(3 \beta) \text { - }\end{array}$ & $\begin{array}{c}\text { Anti-inflammatory, } \\
\text { antibacterial, }\end{array}$ & $\begin{array}{l}\text { Akihisa et al. (2010); } \\
\text { Hichri et al. (2003) }\end{array}$ \\
\hline
\end{tabular}


177 Malik F. H. Ferdosi, Iqra Haider Khan et al. GC-MS Examination of Methanolic ...

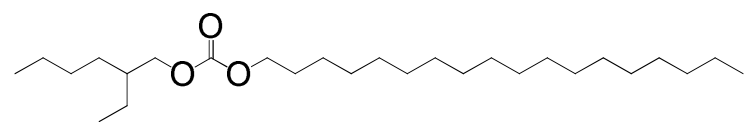

Carbonic acid, 2-ethylhexyl heptadecyl ester<smiles>CCC(C)CCC(C)C1CCC2C3CCC4CC(O)CCC4(CCC23)C1C</smiles><smiles>CCC(C)(C)CCC(C)C1CCC2C1CCC1C2CCC2CC(O)CCC21C</smiles>

Y-Sitosterol

Stigmasterol<smiles>C[C@H]1CCC2(C)CC[C@]3(C)C(=CC[C@]4(C)[C@@H]3CC[C@H]3C(C)(C)C(O)CC[C@]34C)[C@H]2[C@@H]1C</smiles>

$\beta-A m y r i n$

a-Amyrin

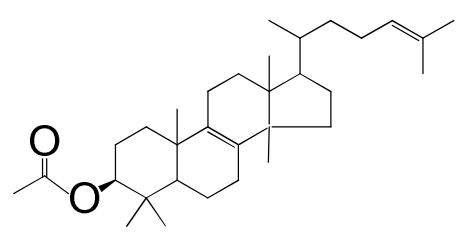

Lanosta-8,24-dien-3-ol, acetate, $(3 \beta)-$

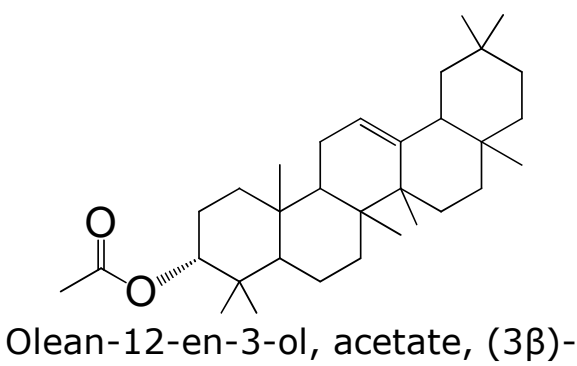

Fig. 1: Structures of compounds in methanolic extract of flowers of Cirsium arvense.

\section{Conclusion}

This methanolic flower extract of $C$. arvense is a rich source of many pharmaceutically important compounds such as olean-12-

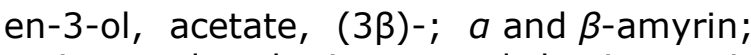
$\gamma$-sitosterol and stigmasterol, having antiinflammatory, antimicrobial, antidiabetic, antioxidant and/or anticancer properties. 


\section{REFERENCES CITED}

Akbar, M., U. Ali, T. Khalil, M.S. Iqbal, A. Amin, R. Naeem, A. Nazir, H.M. Waqas, Z. Aslam, S.I. Jafri, N. Aslam and S.A. Chohan. 2020. Cornus macrophylla, the antibacterial activity of organic leaf extracts and the characterization of the more lipophilic components by GC/MS. Molecules 25: Article 2395.

Akhtar, N., A. Javaid and R. Bajwa. 2001. Herbicidal activity of aqueous extract of Cirsium arvense and Ageratum conyzoides against weeds of wheat. Pak. J. Biol. Sci. 4 (11): 1364-1367.

Akihisa, T., N. Kojima, T. Kikuchi, K. Yasukawa, H. Tokuda, E. Masters, A. Manosroi and J. Manosroi. 2010. Antiinflammatory and chemopreventive effects of triterpene cinnamates and acetates from shea fat. J Oleo Sci. 59: 273-280.

Ali, A., A. Javaid, A. Shoaib and I.H. Khan. 2020. Effect of soil amendment with Chenopodium album dry biomass and two Trichoderma species on growth of chickpea var. Noor 2009 in Sclerotium rolfsii contaminated soil. Egypt. J. Biol. Pest Control 30: Article 102.

Amiri, N., M. Yadegari and B. Hamedi. 2018. Essential oil composition of Cirsium arvense L. produced in different climate and soil properties. Rec. Nat. Prod. 12: 251262.

Bajwa, R. and A. Javaid. 1995. Phytotoxic effect of aqueous shoot extract of Cirsium arvense (L.) Scop. on germination and early growth of cultivated plants. Sci. Int. (Lahore) 7(4): 537-538.

Balamurugan, R., V. Duraipandiyan and S. Ignacimuthu. 2011. Antidiabetic activity of $\mathrm{Y}$-sitosterol isolated from Lippia nodiflora L. in streptozotocin induced diabetic rats. Eur. J. Pharmacol. 667: 410-418.

Banaras S, Javaid A, Shoaib A, Ahmed E (2017). Antifungal activity of Cirsium arvense extracts against a phytopathogenic fungus Macrophomina phaseolina. Planta Daninha 35: e017162738.
Banaras, S., A. Javaid and I.H. Khan. 2021. Bioassays guided fractionation of Ageratum conyzoides extract for the identification of natural antifungal compounds against Macrophomina phaseolina. Int. J. Agric. Biol. 25: 761767.

Cardoso, B.K., H.L.M. de Oliveira, U.Z. Melo, C.M.M. Fermandez, C.F.A.A. Campo and J.E. Goncalves. 2020. Antioxidant activity of $a$ - and $\beta$-amyrin isolated from Myrcianthes pungens leaves. Nat. Prod. Res. 34: 17771781.

Carter, T.R. and R.G. Lym. 2017. Canada Thistle (Cirsium arvense) affects herbage production in the northern great plains. Invas. Plant Sci. Manage. 10: 332-339.

Cheng, J., D. Duan, Y. Wang, L. Ma, Y. Liu and G. Shi. 2012. Acaricidal activity of stigmasterol from Inula britannica against Tetranychus cinnabarinus. In: E. Zhu and S. Sambath (Eds.): Information Technology and Agricultural Engineering, AISC 134, Springer-Verlag Berlin Heidelberg. pp. 599-609.

Dehjurian, A., J. Lari and A. Motavalizadehkakhky. 2017. Antibacterial activity of extract and the chemical composition of essential oils in Cirsium arvense from Iran. J. Essent. Oil Bear. Plants 20: 11621166.

Fernandes, C.P., A.L. Correa, J.F.R. Lob, O.P. Caramel, F.B. de Almeida and L. Rocha. 2013. Triterpene esters and biological activities from edible Fruits of Manilkara subsericea (Mart.) Dubard, Sapotaceae. Biomed Res. Int. 2013: Article 280810.

Hichri, F., H.B. Jannet, J. Cheriaa, S. Jegham and Z. Mighri. 2003. Antibacterial activities of a few prepared derivatives of oleanolic acid and of other natural triterpenic compounds. C. R. Chim. 6(4):473483.

Ingle, K.P., A.G. Deshmukh, D.A. Padole, M.S. Dudhare, M.P. Moharil and V.C. Khelurkar. 2017. Phytochemicals: 
Extraction methods, identification and detection of bioactive compounds from plant extracts. J. Pharm. Phytochem. 6: 32-36.

Jamiołkowska, A. 2020. Natural compounds as elicitors of plant resistance against diseases and new biocontrol strategies. Agronomy 10: Article 173.

Javaid, A., I.H. Khan and A. Shoaib 2018. Management of charcoal rot of mungbean by two Trichoderma species and dry biomass of Coronopus didymus. Planta Daninha 36: e018182795.

Javed, S., Z. Mahmood, K.M. Khan, S.D. Sarker, A. Javaid, I.H. Khan and A. Shoaib. 2021. Lupeol acetate as a potent antifungal compound against opportunistic human and phytopathogenic mold Macrophomina phaseolina. Sci. Rep. 11: Article 8417.

Jiménez-Reyes, M.F., H. Carrasco, A.F. Olea and E. Silva-Moreno. 2019. Natural compounds: A sustainable alternative to the phytopathogens control. J. Chil. Chem. Soc. 64: 44594465.

Kaur, N., J. Chaudhary, A. Jain and L. Kishore. 2011. Stigmasterol: a comprehensive review. Int. J. Pharmaceut. Sci. Res. 2: 2259-2265.

Khan, I.H. and A. Javaid. 2020a. Anticancer, antimicrobial and antioxidant compounds of quinoa inflorescence. Adv. Life Sci. 8: 68-72.

Khan, I.H. and A. Javaid. 2020b. Comparative antifungal potential of stem extracts of four quinoa varieties against Macrophomina phaseolina. Int. J. Agric. Biol. 24: 441-446.

Khan, I.H. and A. Javaid. 2020c. Antifungal activity and GC-MS analysis of $n$-butanol extract of quinoa (Chenopodium quinoa Willd.) leaves. Bangladesh J. Bot. 49: 10451051.

Lichota, A., and K. Gwozdzinski. 2018. Anticancer activity of natural compounds from plant and marine environment. Int. J. Mol. Sci. 19: Article 3533.
Nobarinezhad, M.H., L. Challagundla and L.E. Wallace. 2020. Small-scale population connectivity and genetic structure in Canada thistle (Cirsium arvense). Int. J. Plant Sci. 181: 473484.

Nogueira, A.O., Y.I.S. Oliveira, B.L. Adjafre, M.E.A de Moraes and G.F. Aragao. 2019. Pharmacological effects of the isomeric mixture of alpha and beta amyrin from Protium heptaphyllum: a literature review. Fundam. Clin. Pharmacol. 33: 4-12.

Pinto H.S.A., Pinto L.M.S., Cunha G.M.A., Chaves M.H., Santos F.A., Rao V.S. Anti-inflammatory effect of $a, \beta$ amyrin, a pentacyclic triterpene from Protium heptaphyllum in rat model of acute periodontitis. Inflammopharmacology 16: 48-52.

Sauerschnig, C., M. Doppler, C. Bueschl and R. Schuhmacher. 2018. Methanol generates numerous artifacts during sample extraction and storage of extracts in metabolomics research. Metabolites 8: Article 1.

Sundarraj, S., R. Thangam, V. Sreevani, K. Kaveri, P. Gunasekaran, S. Achiraman and S. Kannan. 2012. YSitosterol from Acacia nilotica $\mathrm{L}$. induces G2/M cell cycle arrest and apoptosis through c-Myc suppression in MCF-7 and A549 cells. J. Ethnopharmacol. 141: 803-809.

Verbeek, J.D. and P.M. Kotanen. 2019. Soil-mediated impacts of an invasive thistle inhibit the recruitment of certain native plants. Oecologia 190: 619-628.

Wang, J., M. Huang, J. Yang, X. Ma, S. Zheng, S. Deng, Y. Huang, X. Yang and P. Zhao. 2017. Anti-diabetic activity of stigmasterol from soybean oil by targeting the GLUT4 glucose transporter. Food Nuri. Res. 61: Article 1364117.

Yang, Y. and J. Lin. 2004. Studies on the constituents from Sambucus chinese. Zhong Yao Cai. 27: 491-492.

Yuan, H., Q. Ma, H. Cui, G. Liu, X. Zhao, W. Li and G. Piao. 2017. How can synergism of traditional medicines 
180 Malik F. H. Ferdosi, Iqra Haider Khan et al. GC-MS Examination of Methanolic ...

benefit from network

pharmacology? Molecules 22: Article 1135.

Zeb, M.A., S.U. Khan, T. Rehman, M. Sajid and S. Seloni. 2017. Isolation and biological activity of $\beta$-sitosterol and stigmasterol from the roots of Indigofera heterantha. Pharm. Pharmacol. Int. J. 5: 204-207. 